\title{
CONSTITUTIONAL LAW: SUPREME COURT FINDS MARITAL PRIVACY IMMUNIZED FROM STATE INTRUSION AS A BILL OF RIGHTS PERIPHERY
}

The United States Supreme Court recently adjudged a Connecticut statute which prohibited the use of contraceptives violative of fourteenth amendment due process because of its application infringing the right of marital privacy. The six opinions delivered by the Court displayed several interpretations concerning the nature and scope of the protection afforded by due process and gave that clause both familiar and novel application.

$\mathrm{T}$

HE TASK of giving content to the phrase "due process of law" as used in the fourteenth amendment $t^{1}$ has been one of the most perplexing to face the Supreme Court. ${ }^{2}$ In a recent confrontation with this problem invoIving the sensitive area of personal liberties the Court, in Griswold $v$. Connecticut, ${ }^{3}$ construed the due process guarantee as broad enough to comprehend an interest in marital privacy.

In Griswold, the Court was presented with the contention that a Connecticut statute making criminal the use of contraceptives ${ }^{4}$ constituted a deprivation of liberty without due process of law.5

\footnotetext{
2 "[N]or shall any State deprive any person of life, liberty, or property, without due process of law ...." U.S. CoNsT. amend. XIV, $\S 1$.

2 See, e.g., Sivisher, The Supreme Court IN MOdern Role 38.59 (1958).

s 381 U.S. 479 (1965), reversing 151 Conn. 544, 200 A.2d 479 (1964).

- Conn. Gen. Stat. ANN. \$ 53-32 (1960): “Any person who uses any drug, medicinal article or instrument for the purpose of preventing conception shall be fined not less than fifty dollars or imprisoned not less than sixty days nor more than one year or be both fined and imprisoned." For a discussion of the origin of the statute and its subsequent legislative history, see Comment, 49 CoRnell L.Q. 275-77, 279-82 (1964); Note, 22 U. PITT. L. Rev. 91, 92-95 (1960); 70 YALE L.J. 322-23 \& n.9 (1960).

- The statute had been assailed as unconstitutional on several occasions and, in each case, was upheld by the Connecticut Supreme Court of Errors. It was adjudged valid in the only criminal prosecution under the statute prior to 1961, State v. Nelson, 126 Conn. 412, 11 A.2d 856 (1940), and in a series of declaratory judgment actions, Trubek v. Ullman, I47 Conn. 633, 165 A.2d 158 (1960), cert. denied and appeal dismissed, 367 U.S. 907 (1961); Buxton v. Ullman, 147 Conn. 48, 156 A.2d 508 (1959) (and companion cases), appeal dismissed sub nom. Poe v. Ullman, 367 U.S. 497 (1961); Tileston v. Ullman, 129 Conn. 84, 26 A.2d 582 (1942), appeal dismissed per curiam, 318 U.S. 44 (1943). The constitutionality of the statute was also upheld in a proceeding to show cause why certain seized contraceptive materials should not be destroyed. State v. Certain Contraceptive Materials, 7 Conn. Supp. 264 (Super. Ct. 1939), set aside on other grounds, 126 Conn. 428, 11 A.2d 863 (1940). The United States Supreme Court twice disposed of appeals from these decisions without a holding on the merits. Poe $v$. Ull. man, 367 U.S. 497 (1961), dismissing appeal from Buxton v. Ullman, 147 Conn. 48, 156 A.2d 508 (1959); Tileston v. Ullman, 318 U.S. 44 (1943) (per curiam), dismissing
} 
The defendants, operators of a planned parenthood medical center at which married persons were counseled in the use of contraceptives, ${ }^{6}$ had been convicted of having assisted others in the violation of the anti-contraceptive statute. ${ }^{7}$

The Supreme Court ${ }^{8}$ reversed the defendants' convictions, holding the statute unconstitutional ${ }^{9}$ as an unjustifiable infringement of the right to marital privacy.10 Mr. Justice Douglas, in an opinion

appeal from 129 Conn. 84, 26 A.2d 582 (1942). In the latter case the Supreme Court ruled that the plaintiff, a physician, lacked standing to litigate the sole constitutional question raised by the record: the danger to the life of his patients if the statute was enforced.

In retrospect, the most recent of these two appeals, Poe v. Ullman, supra, virtually assured a final test of the statute. The Supreme Court dismissed that declaratory judgment action on the grounds that no justiciable controversy was presented because the plaintiffs had not yet violated the statute and because a discernible state policy of nullification by administrative inaction was evinced by the statute's history of nonenforcement. Id. at 501-02, 507-09. It was this interpretation as to the current nonvitality of the statute which led the Planned Parenthood League to open a birth control clinic in New Haven, causing the arrests of its executive and medical directors. Comment, 49 CoRnelt L.Q. 275, 295-96 (1964).

- During its ten days of operation, the clinic offered lectures to married persons concerning the use of contraceptives, gave physical examinations and distributed contraceptive devices for a graduated fee based on income. Its directors, Mrs. E. T. Griswold and Dr. C. L. Buxton, were fined one hundred dollars each. Brief for Appellants, pp. 2, 4-5. Their convictions were affirmed in the state's appellate courts. Connecticut v. Griswold, 151 Conn. 544, 200 A.2d 479 (1964).

7 The Connecticut accessory law, ConN. Gen. STAT. ANN. \$ 54-196 (1960), makes one a principal offender if he counsels or abets another in the commission of "any offense."

${ }^{8}$ The Court exercised appellate jurisdiction under 28 U.S.C. $\$ 1257$ (2), which provides for right of appeal to the Supreme Court where the highest court of a state upholds the validity of a state statute challenged as being repugnant to the Constitution, treaties or laws of the United States.

${ }^{\circ}$ It is not clear from the opinion of the Court or the concurring opinions whether the Connecticut anti-use statute is unconstitutional on its face or merely unconstitutional as enforced against married couples. Defendants sought both holdings. Brief for Appellants, pp. 3-4, 96. Two members of the Court have stated that, in their view, the Connecticut legislation as applied to married persons violated the due process guarantee of the fourteenth amendment. 381 U.S. at 502 (White, J., concurring); Poe v. Ullman, 367 U.S. 497, 539, 555 (1961) (Harlan, J., dissenting). The centrality of the right of marital privacy in the opinions of the other Justices voting to reverse the defendants' convictions, suggests that the Court was thinking in terms of voiding the statute in the more limited, "as applied," sense. The issue is by no means academic since the Attorney General of Connecticut may have to decide whether the "existing" statute is sufficiently viable to authorize the state to prosecute unmarried persons for using contraceptives, or, more realistically, to authorize prosecution of birth control clinics dispensing contraceptive information and materials to unmarried persons, or whether new legislation for that purpose is needed. Justices White and Goldberg indicated that an anti-use statute covering unmarried persons alone would not be constitutionally objectionable. 381 U.S. at 498,502 .

${ }^{10}$ To defend against their criminal prosecution by raising the marital rights of clinic patients, the defendants first had to persuade the Court that they had "an interest ... . worthy of legal protection from the effects of unconstitutional governmental action." Lewis, Constitutional Rights and the Misuse of "Standing," 14 STAN. L. REv. 433 (1962). 
joined by four other members of the Court, 11 found this right protected by emanations from the first, third, fourth, and fifth amendments. ${ }^{12}$ However, three of the five who concurred with

Only by such a showing could the application of the general rule that parties may rely solely on constitutional rights personal to themselves, Tileston v. Ullman, 318 U.S. 44 (1943), be avoided. The Court resolved this initial problem of standing, as presented here in its jus tertii form, in favor of the defendants, and alluded to several significant factors in so deciding. While the defendants were without standing to raise constitutional questions in their own right, as the parties being prosecuted in a criminal proceeding they stood to be adversely and injuriously affected unless permitted to "assert that the offense which ... [they were] charged with assisting is not, or cannot constitutionally be, a crime. ..." 381 U.S. at 481 . This defense necessarily involved an inquiry into the incidence of the statute upon the privacy of married couples served by the defendants. The interest of the defendants, then, was a direct one since if the action of government was unconstitutional with regard to married couples, it was also unconstitutional as applied through the accessory statute to alleged abetters in the proscribed offense. See Sedler, Standing to Assert Constitutional Jus Tertii in the Supreme Court, 71 YALE L.J. 599, 606 n.35, 641 n.177a (1962). In addition, the Court stressed the pre-existing "professional relationship" involved, 381 U.S. at 481, and cited several cases involving a parallel professional relationship such as parent and pupil vis-à-vis teacher, in which rights of one party to the relationship were raised successfully by the other. See Adler v. Board of Educ., 342 U.S. 485 (1952); Pierce v. Society of Sisters, 268 U.S. 510 (1925); Meyer v. Nebraska, 262 U.S. 390 (1923); Bartels v. Iowa, 262 U.S. 404 (1923).

Perhaps a more weighty factor was the probable impairment of the rights of husband and wife under the statute if such rights had not been vindicated by the Court. 381 U.S. at 481 . The freedom of married persons to use or not to use contraceptives as they so decide would seem to include as a necessary adjunct not only access to contraceptive materials but also access to medical counsel concerning the advisability and proper manner of such use. A successful prosecution of the competent sources of this advice which effectively precludes the offering of these services impinges in a definite, qualitative way on marital freedom. Moreover, the mere existence of the anti-use statute on the books will ostensibly lave an intimidating and inhibitory effect on the use itself and the state, by not enforcing the law against married persons, could prevent any assertion by them of their alleged constitutional rights. In this situation, the defendants, as the only effective representatives of these rights, were permitted to bring them to the attention of the Court. See United States v. Raines, 362 U.S. 17, 22 (1960); Barrows v. Jackson, 346 U.S. 249 (1953). "[T]he reasons which underlie our rule denying standing to raise another's rights, which is only a rule of practice, are outweighed by the need to protect the fundamental rights which would be denied by permitting the ... action to be maintained . . . Id. at 257. See Sedler, supra at $628,647-48,650-51$. A third factor which may have been implicit in the decision to accord standing is suggested by Professor Sedler, who finds a variance in standing requirements which turns on the nature of the right asserted, with basic freedoms such as privacy apparently occupying a sensitive position in our "hicrarchy" of values. Id. at 628. See 381 U.S. at 486, 494-95, 503 .

The requirement that there be an actual, justiciable controversy before the court, an issue closely related to and often inextricably tied up with standing and one which was fatal to the attempted challenge to the Connecticut statute in Poe v. Ullman, 367 U.S. 497 (1961), see note 5 supra, was met in Griswold by reason of the criminal conviction.

${ }^{11}$ Mr. Chief Justice Warren, and Justices Douglas, Clark, Brennan, and Goldberg comprised the majority. 381 U.S. at 480-86. The Chief Justice and Mr. Justice Brennan also joined in the separate concurring opinion of Mr. Justice Goldberg. Id. at 486.99.

12 These amendments presumably are made applicable here to state action by the 
Douglas, Justices Goldberg, Brennan and the Chief Justice, did not deem the presence or absence of the marital interest among the provisions of the Bill of Rights to be controlling. Joining in the concurring opinion of Mr. Justice Goldberg, ${ }^{13}$ they emphasized that marital privacy is constitutionally protected because of its nature as a "fundamental right."14 To support the conclusion that the interests protected by the due process clause of amendments five and fourteen are not circumscribed by the specific guarantees of the Bill of Rights, Mr. Justice Goldberg relied upon amendment nine ${ }^{15}$ as evidence of the concern of those who adopted the first eight amendments that the rights enumerated therein not be thought exhaustive. ${ }^{18}$ Justices Harlan and White, each concurring in the judgment in a separate opinion, agreed that the broad Connecticut interdiction invaded a constitutionally protected area of privacy, but found no necessity for reference to the ninth amendment or to emanations from the Bill of Rights. ${ }^{17}$ The dissenters, Justices Black and Stewart, denied that the Constitution anywhere contained an explicit guarantee preserving marital privacy against governmental intrusion. ${ }^{18}$

fourteenth amendment. Mr. Justice Douglas would make all of the first eight amendments binding on the states on the theory that the content of the fourteenth amendment due process guarantee includes the same immunities as those granted by the Bill of Rights. Douglas would not, however, limit fourteenth amendment due process to the scope of the Bill of Rights. Poe v. Ullman, 367 U.S. 497, 515-17 (1961) (dissenting opinion).

The view of a majority of the Court on this point, however, has been that due process secures against state infringement only "basic" Bill of Rights freedoms which "cannot be denied without violating those fundamental principles of liberty and justice which lie at the base of all civil and political institutions-principles which the Fourteenth Amendment embodies in the general terms of its due process clause." De Jonge v. Oregon, 299 U.S. 353, 364 (1937).

The opinions of Justices Goldberg and Harlan clearly reflect the latter interpretation of due process. See note 20 infra. Mr. Justice Black has espoused the former, minority view, generally referred to as the "incorporation theory." However, Black would make due process synonymous in meaning and scope with the content of the Bill of Rights. See notes 31-32 infra and accompanying text. The position of $\mathrm{Mr}$. Justice Stewart is somewhat ambiguous, for while he apparently does not subscribe to the "incorporation theory," his position in Griswold evidences an unwillingness to go beyond the terms of the Bill of Rights in applying fourteenth amendment due process. See 381 U.S. at $528 \&$ n.1.

13381 U.S. at 486.

14 Id. at 486-88, 494-96, 499.

15 "The enumeration in the Constitution, of certain rights, shall not be construed to deny or disparage others retained by the people." U.S. CoNST. amend. IX.

10381 U.S. at $488-92$.

${ }^{17} \mathrm{Id}$. at 499.502, 502-07.

${ }^{18}$ Each dissenter joined in the separate opinion of the other. Id. at 507 (Black, J., dissenting); Id. at 527 (Stewart, J., dissenting). 
Certain of the analytical approaches utilized by various members of the Court to determine the applicability and scope of the fourteenth amendment protection are familiar. Mr. Justice Harlan persisted in his position ${ }^{19}$ that due process prohibits unwarranted state interference with fundamental values necessary to a scheme of ordered freedom. ${ }^{20}$ When the interest at stake is highly prized, as is privacy in an intimate aspect of the husband-wife relationship, the challenged enactment must have a compelling raison d'etre, which the state here failed persuasively to supply. ${ }^{21}$

${ }^{18}$ See Pointer v. Texas, 380 U.S. 400, 408.09 (1965) (Harlan, J., concurring); Gideon v. Wainwright, 372 U.S. 335, 352 (1963) (Harlan, J., concurring); Mapp v. Ohio, 367 U.S. 643, 682 (1961) (Harlan, J., dissenting); Roth v. United States, 354 U.S. 476, 502 (1957) (Harlan, J., concurring).

20381 U.S. at 500; Poe v. Ullman, 367 U.S. 497, 541, 548-49 (1961) (Harlan, J., dissenting). Mr. Justice Harlan directs the reader in Griswold to his opinion in Poe v. Ullman, supra, for an extensive evaluation of the anti-use statute in terms of the relevant due process requirements. 381 U.S. at 500 .

By flexibly defining the coverage of the due process guarantee to embrace "fundamental values," Mr. Justice Harlan spoke in the tradition of Justices Cardozo and Frankfurter, who led the Court in rejecting any crystallized, predetermined meaning for that clause. See, e.g., Adamson v. California, 332 U.S. 46, 62-67 (1947) (Frankfurter, J., concurring); Palko v. Connecticut, 302 U.S. 319 (1937) (opinion of the Court delivered by Cardozo, J.); Kadish, Methodology and Criteria in Due Process Adjudication-A Survey and Criticism, 66 YALE L.J. 319, 326 (1957), in SELECTED IsSAYS ON CONSTITUTIONAL LAW 522, 528 (1963). See generally Frankfurter, Memorandum on "Incorporation" of the Bill of Rights into the Due Process Clause of the Four. teenth Amendment, 78 HARv. L. Rev. 746 (1956). Mr. Justice Goldberg may also be characterized as adopting this "flexible" due process approach. See note 14 supra and accompanying text. However, once a provision of the Bill of Rights has been found to apply to the states by force of amendment fourteen, Mr. Justice Goldberg would require a state to satisfy the same standard as has governed federal activity under that provision. Pointer v. Texas, 380 U.S. 400, 413 (1965) (Goldberg, J., concurring); Malloy v. Hogan, 378 U.S. 1, 10-11 (1964); cf. Pointer v. Texas, supra at 408-09 (Harlan, J., concurring); Malloy v. Hogan, supra at 14-33 (Harlan, J., dissenting).

It is important to note that there is a distinction in the practical effect, if not in the content as well, of the implementation of this flexible due process approach by the current and earlier Justices. The primary concern of the earlier Justices in the advocacy of this approach was to establish that the fourteenth amendment did not prohibit state action in all areas declared inviolable against federal activity by the Bill of Rights, but that it impeded state regulation only in those areas occupied by fundamental interests. While some of the guarantees in the first eight amendments have been deemed "fundamental" by the Court, e.g., Cantwell v. Connecticut, 310 U.S. 296 (1940) (fourteenth amend́ment due process embraces first amendment guarantees of free exercise of religion and speech), others have not, e.g., Wagner Elec. Mfg. Co. v. Lyndon, 262 U.S. 226 (1923) (right of trial by jury in state court not required by Constitution). More recently, however, flexible due process has been utilized in urging vindication of interests entirely outside the terms of the Bill of Rights, Griswold being a notable example of this use. Cf. Kent v. Dulles, 357 U.S. 116, 125-27 (1958) (right to travel insured under fifth amendment due process).

${ }_{21}$ Poe v. Ullman, supra note 20, at 545, 553-54. Here, as in the past, Mr. Justice Harlan balanced the competing claims of the state and the citizen in order to resolve the conflict between them. See, e.g., Smith v. California, 361 U.S. 147, 170-71 (1959) (Harlan, J., concurring in part and dissenting in part). 
A second familiar approach is seen in Mr. Justice White's adoption of a "reasonableness" due process inquiry, a customary modus operandi of the Court in the field of civil liberties. ${ }^{22}$ Mr. Justice White first noted that the freedom of married persons jeopardized by this sweeping prohibition falls within a "sensitive area of liberty" given judicial cognizance in prior cases, and the state consequently "bears a substantial burden of justification." $23 \mathrm{He}$ recognized that the statute's objective of discouraging illicit sexual relationships was "permissible and legitimate." 24 However, because of its unnecessarily broad reach, ${ }^{25}$ the existence of other criminal statutes aimed at this same evil, ${ }^{26}$ and the general availability of contraceptives in Connecticut for "disease-prevention," 27 he concluded that the anti-use statute was neither necessary nor rationally connected to its avowed objective. In the absence of the requisite

${ }^{22}$ This test is designed to discover whether a given instance or pattern of state action has as its design a proper governmental objective and, if so, whether the action is a rational means of effectuating that objective. Aptheker v. Secretary of State, 378 U.S. 500 (1964); Gibson v. Florida Legislative Investigating Comm., 372 U.S. 539 (1963); Cohen v. Hurley, 366 U.S. 117, 123-25 (1961); Konigsberg v. State Bar, 366 U.S. 36, 49-51 (1961); Bolling v. Sharpe, 347 U.S. 497 (1954); Whitney v. California, 274 U.S. 357, 371 (1927). The necessary substantiality of the nexus between the state law or action and the objective served varies directly with the inportance, in our scheme of social values, attached to the individual interest threatened. See Schneider v. State, 308 U.S. 147, 161 (1939). A weighing or balancing of the "equities" involved in the rival interests is thus a basic feature of the "reasonableness" method of constitutional interpretation. See Strong, Trends in Supreme Court Interpretation of Constitution and Statute, 6 WAYNE L. REv. 285, 307 (1960).

23381 U.S. at 502-03.

${ }^{24}$ Id. at 505. Counsel for the defendants enumerated five distinct legislative objectives which had been recognized by Connecticut courts in prior actions disputing the validity of the anti-contraceptive statute: the protection of persons from the use of drugs or devices injurious to health or life, Brief for Appellants, pp. 25, 26-27; the maintenance and increase of the population, $i d$. at 25, 27-29; the restriction of sexual intercourse to the propagation of legitimate children, $i d$. at $25,30-31$; the promotion of public morals by prohibiting the use of particular methods of avoiding conception, such as those employing extrinsic aids, even within the marital relation, id. at 25, 31-74; and the protection of public morals by discouraging sexual intercourse outside the marital relationship, id. at $25,75-78$.

${ }^{25}$ The feasibility of a less objectionable, more discriminately tailored statute which could effectively combat the same substantive evil, illicit and immoral sexual behavior, is relevant in this due process inquiry since "the breadth of legislative abridgment must be viewed in the light of less drastic means for achieving the same basic purpose." Shelton v. Tucker, 364 U.S. 479, 488 (1960). "A statute limiting its prohibition on use to persons engaging in the prohibited relationship would serve the end posited by Connecticut in the same way, and with the same effectiveness, or ineffectiveness, as the broad anti-use statute under attack in this case. I find nothing in this record justifying the sweeping scope of this statute, with its telling effect on the freedoms of married persons ...." 381 U.S. at 507 (White, J., concurring).

${ }^{20} I d$. at 505. CoNN. GEN. STAT. ANN. $\$ \S 53-218$ to -219 (1960), proscribe adultery, fornication, and lascivious carriage.

${ }^{27} 381$ U.S. at 505. 
overriding state interest in the statute, Mr. Justice White adjudged it void as arbitrary legislation under the fourteenth amendment.

In a vigorous dissent, $\mathrm{Mr}$. Justice Black ${ }^{28}$ consolidated a theory of due process ${ }^{29}$ which he had developed and articulated in prior writings. $^{30} \mathrm{He}$ has contended long and unsuccessfully for the view that the fourteenth amendment summarily "incorporated" the various provisions of the Bill of Rights, ${ }^{31}$ and also, by implication, that those enumerated rights constitute the full and exclusive measure of the area of protected interests under the due process clause of the fourteenth amendment. ${ }^{32}$ The result would be to infuse a more fixed and certain meaning into the due process concept.

Against this background and with some amplification of his views, it is not surprising to find Mr. Justice Black levelling severe criticism at the presumptuousness of the Court's invalidation of a state law which cannot be said to conflict with any right guaranteed

${ }^{28} 381$ U.S. at 507 (dissenting opinion). The opinion of $\mathrm{Mr}$. Justice Black is discussed here with no further mention of the companion dissenting opinion of $\mathrm{Mr}$. Justice Stewart because Black has been the leading protagonist of, and his opinion gives fuller treatment to, the restrictive concept of due process which is the underlying rationale of both dissents.

20 Except for the substantive meaning of due process, described in text accompanying notes 31-32 infra, Mr. Justice Black views that clause as designed primarily to ensure certain procedural safeguards in criminal proceedings. See Chambers v. Florida, 309 U.S. 227, 235-37 (1940) (Black, J.).

so See inaterials cited notes 31-32 infra.

${ }^{31}$ Beauharnais v. Illinois, 343 U.S. 250, 269, 272-75 (1952) (Black, J., dissenting); Adamson v. California, 332 U.S. 46, 71-75, 89 (1947) (Black, J., dissenting); Betts v. Brady, 316 U.S. 455, 474 (1942) (Black, J., dissenting); Rogge, "Concept of Ordered Liberty," 47 CALIF. L. REv. 238, 252-53 (1959). This controversial issue was decided against Mr. Justice Black in Adamson v. California, supra, where the Court decided that the due process safeguard was more flexible in its contours than a mere "shorthand reference" to the specific immunities in the first eight amendments. Accord, Palko v. Connecticut, 302 U.S. 319, 323-27 (1937); Twining v. New Jersey, 211 U.S. 78 (1908); Furtado v. California, 110 U.S. 516 (1884). See generally Swisher, op. cit. supra note 2, at 38-59. Professor Morrison analyzes the judicial framework in which this controversy took place. Morrison, Does the Fourteenth Amendment Incorporate the Bill of Rights?, 2 STAN. L. REv. 140 (1949). The narrow holding in Adamson v. California, supra, that the fifth amendment's prohibition against involuntary self-incrimination was not a part of the fourteenth amendment's due process protection was overruled in Malloy v. Hogan, 378 U.S. 1 (1964). However, Adamson's rejection of an interpretation of fourteenth amendment due process which would automatically incorporate the Bill of Rights has remained intact.

For a statement of Mr. Justice Black's thesis that the Bill of Rights guarantees are to be giveu a broad interpretation and uncompromising enforcement, see Black, The Bill of Rights, 35 N.Y.U.L. REv. 865 (1960).

s2 See Jackson v. Denno, 378 U.S. 368, 407-08 (1964) (Black, J., dissenting in part); Comment, 58 Yale L.J. 268, 271 \& n.18 (1949), in Selected Essays on Constitutional, LAw 506, 508 (1963). 
by express statement or necessary implication of the Bill of Rights. ${ }^{33}$ $\mathrm{He}$ asserted that employment of the flexible due process analysis used in the concurring opinions permits a judge to find a law arbitrary if, merely by his personal appraisal, he considers it unwise or offensive by its violation of a "fundamental right" derived from vague natural law notions. ${ }^{34}$ Black likened this jurisprudential technique to that found in the since repudiated decisions of the Supreme Court proscribing state economic legislation..$^{35} \mathrm{He}$ warned that to make such an indefinite formula the standard of constitutionality arrogates to the Court distinctly legislative functions, a usurpation which portends disruptive consequences for the constitutional separation and balance of powers doctrines. ${ }^{36}$

Although many venerable theories of due process were thus refurbished in the garb of a new context, the question in Griswold did elicit from the Court some innovation in constitutional doctrine. In the context of those fourteenth amendment due process interpretations which consider the content of the Bill of Rights pivotal, the "peripheral rights theory" of the majority opinion permitted an extension of the constitutional protection of privacy generally and a relaxation of the propinquity required between an interest and its related Bill of Rights guarantee for the former to be given status as a constitutional right. The concept of privacy as a major factor to be consciously weighed by the courts in adjusting the relationship between a citizen and his government has found its way into judicial opinions and decisions in recent years. ${ }^{37}$ But in

\footnotetext{
33 U.S. at 520-21 (dissenting opinion).

${ }^{34}$ Id. at 511-13 (dissenting opinion). See FPG v. Natural Gas Pipeline Co., 315 U.S. 575, 600 n.4 (1942) (Black, Douglas, and Murphy, JJ., concurring).

${ }^{36} I d$. at 514-16, 522-24. In a series of decisions beginning with Lochner v. New York, 198 U.S. 45 (1905), and ending with Nebbia v. New York, 291 U.S. 502 (1934), state economic legislation was invalidated for its "unreasonable" interference with contract and property interests. The Court arguably substituted its judgment as to the wisdom and propriety of such laws for that of the legislature: "[T] he only general rule which could be drawn from the decisions was that types of regulation of which the Court sufficiently disapproved were unconstitutional." Stern, The Problems of Yesteryear-Commerce and Due Process, 4 VAND. L. REv. 446, 448 (1951). See Ferguson v. Skrupa, 372 U.S. 726, 729-32 (1963); LOCKHART, KAMISAR \& CHOPER, CoNSTITUTIONAL LAw 576-79 (1964).

so 381 U.S. at 513, 521. "Subjecting federal and state laws to such an unrestrained and unrestrainable judicial control as to the wisdom of legislative enactments would, I fear, jeopardize the separation of governmental powers that the Framers set up and at the same time threaten to take away much of the power of States to govern themselves which the Constitution plainly intended them to have." Id. at 521 .

${ }^{37}$ See cases cited in Beaney, The Constitutional Right to Privacy in the Supreme Court, 1962 SuP. CT. REv. 212; Comment, 40 N.C.L. REv. 788 (1962).

The tort concept of privacy has seen an earlier and more extensive development,
} 
each case the authoritative force of the argument for privacy has been dependent on the proximate involvement of a particular enumerated right, itself threatened in some way by the governmental action challenged, to which the privacy interest stood in close, logical relation. ${ }^{38}$ In Griswold, however, marital privacy could not be vindicated by reference to any specific right accorded by the terms of the first eight amendments. Instead, Mr. Justice Douglas asserted that certain of the first eight amendments, by establishing peripheral "zones of privacy," contribute to an underlying, generalized right

to the extent that judicial recognition of a man's "right to be let alone" has presently been secured in an ever-expanding variety of application. See Prosser, Torts $\S 112$, at 833-34 (3d ed. 1964).

${ }^{38}$ Certain of the guarantees in the first eight amendments have been regarded as creating a right of privacy "at certain times and places with respect to certain activities." 381 U.S. at 508 .

(1) A privacy interest has been identified in the conflict of the first amendment's protection of speech with a statutory prohibition against advocation of pacifism which could be applied to parent-child communication within the home. Gilbert v. Minnesota, 254 U.S. 300, 334-35 (1920) (Brandeis, J., dissenting).

(2) A privacy interest has likewise been identified in the conflict of the first amendment's protection of "association" with the forced disclosure of the membership list of a private organization (Gibson v. Florida Legislative Investigation Comm., 372 U.S. 539, 544 (1963); Bates v. Little Rock, 361 U.S. 516, 523 (1960); NAACP v. Alabama, 357 U.S. 449, 462 (1958); see Louisiana v. NAACP, 366 U.S. 293 (1961)), and with the forced disclosure of private political loyalties, Sweezy v. New Hampshire, 354 U.S. 234, 248 (1957).

(3) A privacy interest has been identified in the conflict of the fourth amendment's security against unreasonable searches and seizures with eavesdropping by government agents by any of a number of devices into a person's residence or place of business. Irvin v. California, 347 U.S. 128, 149-52 (1954) (Douglas, J., dissenting); On Lee v. United States, 343 U.S. 747, 762-65 (1952) (Douglas, J., dissenting); Goldman v. United States, 316 U.S. 129, 136-42 (1942) (Murphy, J., dissenting); Olmstead v. United States, 277 U.S. 438, $471-85$ (1928) (Brandeis, J., dissenting); Silverman v. United States, 275 F.2d 173, 178-80 (D.C. Cir. 1960) (Washington, J., dissenting), rev'd on other grounds, 365 U.S. 505 (1961). See also id. at 512-13 (Douglas, J., concurring).

(4) A privacy interest has been identified in the conflict of the fourth amendment's security against unreasonable searches and seizures with allegedly arbitrary intrusions into one's home (Mapp v. Ohio, 367 U.S. 643 (1960); Frank v. Maryland, 359 U.S. 360, 367 (1958); id. at 374 (Douglas, J., dissenting); Wolf v. Colorado, 338 U.S. 25, 30-31 (1949) (dictum); Boyd v. United States, 116 U.S. 615, 630 (1886) (Waitc, C.J., concurring)), and with searches of one's person (Wilson v. Schnettler, 365 U.S. 381, 394-98 (1961) (Douglas, J., dissenting); Monroe v. Pape, 365 U.S. 167 (1961); Rochin v. California, 342 U.S. 165, 172 (1952); York v. Story, 324 F.2d 450 (9th Gir. 1963), cert. denied, 376 U.S. 939 (1964)).

(5) Finally, a privacy interest has been identified in the conflict of the fifth amendment's privilege against self-incrimination with the introduction in a criminal trial of unlawfully seized evidence which is incriminating to defendant. Olmstead v. United States, supra at 471, 474-79 (Brandeis, J., dissenting); Boyd v. United States, supra at 630,633-35; id. at 639 (Waite, C.J., concurring). See also Watkins v. United States, 354 U.S. 178, 187-88 (1957) (appeal of contempt-of-Congress conviction for refusal to answer investigation committee questions). See generally Griswold, The Right to be Let Alone, 55 Nw. U.L. REv. 216 (1960); Nutting, The Fifth Amendment and Privacy, 18 U. PITT. L. REv. 533 (1957). 
in a citizen to remain secure from arbitrary, official intrusion into his private affairs. ${ }^{39}$ Marital privacy, as an exemplary manifestation of this right, was found to lie within this zone and is thus to be protected against demeaning legislation by the Bill of Rights as applied through the fourteenth amendment. By perceiving in the spirit of several Bill of Rights immunities, considered together, a design to preserve that non-enumerated interest inviolate, the Court went beyond its previous treatment of the Bill of Rights in interpretive technique and result. ${ }^{40}$

An equally significant development in the judicial process of defining fourteenth amendment due process is Mr. Justice Goldberg's use of the ninth amendment as support for the conclusion that marital privacy, while not explicitly mentioned in the Bill of Rights, is nonetheless a constitutional right.1 Griswold marks the first case in which the ninth amendment has been employed, albeit indirectly, as a substantive check on governmental action. ${ }^{42}$ The role of the ninth amendment in the context of the Court's nullification of a state law is also remarkable in view of the original aim of that amendment as an indirect limitation on the federal government. Its relevance to the states is explained by Mr. Justice Goldberg as being the logical corollary of that aim: insofar as the ninth amendment was intended to ensure that the content of the Bill of Rights is not regarded as the full measure of the fifth amendment's due process guarantee, then neither should the due process clause of the fourteenth amendment be interpreted as encompassing only those enumerated rights. ${ }^{43}$

${ }^{30} 381$ U.S. at 484-85. See also Beaney, supra note 37, at 214.

${ }^{10}$ See note 38 supra and accompanying text.

11381 U.S. at 495-96.

"See generally Kelsey, The Ninth Amendment of the Federal Constitution, 11 IND. L.J. 309, 319 (1936); Redlich, Are There "Certain Rights . . Retained By The People", 37 N.Y.U.L. REv. 787, 804-10 (1962). For judicial construction of the ninth amendment, see generally Patterson, The Forgorten NinTh AMENDMENT 27-35 (1955). In United Pub. Workers v. Mitchell, 330 U.S. 75, 94-104 (1947), the Court accepted the contention that enforcement of the Hatch Act would interfere with the right of a citizen to act as a party official or worker in order to further his own political views, a political right reserved to the people under the ninth and tenth amendments. However, the Court held such interference justifiable as a reasonable limitation imposed to further legitimate governmental interest.

The use of the ninth amendment in a privacy context seems particularly apt since privacy, in its broadest meaning, may be thought of as describing a vital area of individual personality and freedom immune from governmental intrusion, a concept roughly coextensive with that aggregate of "other rights retained by the people" guaranteed by the ninth amendment.

${ }^{43} 381$ U.S. at 493. See Redlich, supra note 42 , at 787,807 . For the thesis that the 
Mr. Justice Goldberg's opinion may be said to have vitalized the ninth amendment, if only to the extent of affirming the propriety of its supplemental use to support an expansive, flexible construction of the breadth of the due process protection.44 In addition, the opinion has a negative implication with regard to the force of the "peripheral right" theory. Although Justices Goldberg and Brennan and the Chief Justice gave that theory the stature of the majority view by their concurrence, the salient point of their separate opinion actually undercut its efficacy by making it unnecessary to the Court's holding. The determinative consideration for these Justices is the fundamental character of the interest and not its inclusion in the language of the flrst eight amendments. An assessment of the future utility of a peripheral right approach in the resolution of a conflict between state action and an "independent" right should therefore not disregard the fact that only one other member of the Court, Mr. Justice Clark, was content to rest the decision in Griswold on that juridical basis.5

ninth amendment was not intended to operate merely as a restraint on federal power but rather as a declaration of general applicability affirming the existence of inherent liberties, see Patrerson, op. cit. supra note 42 , at 36-43.

«s 381 U.S. at 486.87, 493. Mr. Justice Goldberg is careful to qualify his introduction of this amendment by stressing that he does not mean "to imply that the Ninth Amendment is applied against the States by the Fourteenth ... or ... to state that the Ninth Amendment constitutes an independent source of rights protected from infringement by either the States or the Federal Government." Id. at 492. (Emphasis added.)

The argument has been made that this textual tool, utilized to illuminate the existence of other deeply felt, personal concerns outside the Bill of Rights, has a potentiality of wide and versatile application. See PATTERson, op. cit. supra note 42, at 44-56. But see Rogge, Unenumerated Rights, 47 CAlIF. L. REv. 787, 826 (1959), for the assertion that the ninth amendment has played and will play only a small role, incidental to the due process clauses, in protecting unenumerated interests.

${ }^{15}$ An actual majority of the Court viewed fourteenth amendment due process as not limited by the Bill of Rights, as is evident from the fact that five Justices appraised marital privacy as a constitutionally protected interest to be characterized more as independent of than derivative froin the first eight amendments. Neither Mr. Justice Harlan nor Mr. Justice White resorted to the Bill of Rights as primary authority by which to determine the status of marital privacy. Further, although Mr. Justice Goldberg, speaking for two other members of the Court, did concur in the opinion of the Court, the decisive emphasis of his opinion was that privacy must be preserved here for the reason that it is among those "fundamental personal rights ... protected from abridgment by the Government though not specifically mentioned in the Constitution." 381 U.S. at 496 (concurring opinion).

It is of interest to observe in this connection that in his dissenting opinion in Poe v. Ullman, 367 U.S. 497 (1961), Mr. Justice Douglas himself regarded the Connecticut statute as an invasion of "the privacy that is implicit in a free society" and did not feel constrained to bring the privacy interest within the purview of the Bill of Rights in order to protect it via due process. Id. at 516, 518-19, 521 (dissenting opinion). By construing the Bill of Rights to include privacy in Griswold, he was able 
The "fundamental interest" concept relied on by Justices Goldberg and Harlan ${ }^{46}$ represents a means simultaneously of giving content to and of limiting the scope of flexible due process. Two objections may be raised to this conceptual guideline. First, whether or not an interest is deemed fundamental would seem to turn more on a judge's subjective value preferences rather than any identifiable, independent principles of law.47 This vulnerability is distressingly evident when interests over the intrinsic worth of which there is no such general consensus as obtained in Griswold are posed before the Court as the object of alleged abridgment by state action. ${ }^{48}$ Secondly, while the Court has in the past recognized interests outside the language and immediate implications of the Bill of Rights as worthy of constitutional protection, ${ }^{49}$ its primary concern in these cases has been the arbitrary character of the governmental action involved. ${ }^{50}$

to contract the ground on which he would be vulnerable to professional criticism to the more "narrow one" of constitutional interpretation and thereby avoid exposing himself to question on the much "more basic" jurisprudential issue concerning the proper function of judicial review. See 381 U.S. at 5 II (Black, J., dissenting).

10381 U.S. at 486-88, 492 (Goldberg, J., concurring); id. at 499, 500 (Harlan, J., concurring); Poe v. Ullman, 367 U.S. 497, 541, 548, 554 (1961) (Farlan, J., dissenting).

${ }^{17}$ In his concurring opinion in Irvine v. California, 347 U.S. 128 (1954), Mr. Justice Clark observed that "in truth, the practical result of this ad hoc approach [to due process] is simply that when five Justices are sufficiently revolted by local police action, a conviction is overturned and a guilty man may go free." Id. at 138.

18 The frequency of close decisions, many involving a five-to-four split, in cases alleging state action inconsistent with fundamental interests, e.g., Harris v. South Carolina, 398 U.S. 68 (1949); Turner v. Pennsylvania, 338 U.S. 62 (1949); Haley v. Olio, 332 U.S. 596 (1948), would seem to suggest that this flexible due process analysis has not provided clearly ascertainable and objective criteria for its concrete application. See Swisher, op. cit. supra note 2 , at 41 .

10 E.g., Apetheker v. Secretary of State, 378 U.S. 500 (1964) (interest in free travel guaranteed by fifth amendment due process); NAACP v. Alabama, 357 U.S. 449 (1958) (interest in inviolability of privacy in group association); Schware v. Board of Pub. Examiners, 353 U.S. 232 (1957) (interest in pursuing a career in law); Bolling v. Sharpe, 347 U.S. 497 (1954) (interest in attending non-segregated public schools as a matter of fifth amendment due process); United Pub. Workers v. Mitchell, 330 U.S. 75 (1947) (interest of a citizen in furthering his political views by appropriate party activity guaranteed by flfth amendment due process); Pierce v. Society of Sisters, 268 U.S. 510 (1925) (interest of parents to direct the upbringing of their children); Myer v. Nebraska, 262 U.S. 390 (1923) (interest of a teacher to teach and a pupil to study a modern foreign language). Cf. Kent v. Dulles, 357 U.S. 116 (1957).

${ }^{\circ}$ For example, in Apetheker v. Secretary of State, supra note 49, the Court focused on the overly broad and indiscriminate scope of the interdiction upon travel which rendered the statutory provision in question constitutionally defective. Id. at 514 . In NAACP v. Alabama, supra note 49, the Court concluded that since "Alabama has fallen short of showing a controlling justification for the deterrent effect on the free enjoyment of the right to associate which disclosure of membership is likely to have," such disclosure could not be demanded under the fourteenth amendment. Id. at 466 . In Schware v. Board of Pub. Examiners, supra note 49 , the Court ruled that when 
In view of these criticisms, Mr. Justice White may be thought to have adopted a sounder method. Central to the reasonableness due process inquiry is an examination of the relation between the objective desired by government and the means selected to achieve it, the absence of a rational relation being the definition of "arbitrary" action. ${ }^{51}$ Moreover, since only a tenuous connection between the state's legitimate objective and its chosen mode of reaching it will be required where the personal interests invaded are insubstantial, it becomes unnecessary to posit a doctrinal qualification on the fourteenth, or fifth, amendment as is done when it is said to be operational only if a "fundamental" interest is involved. Further, this approach possesses the merit of judicial candor by assigning openly a certain weight to the interest under consideration, which the Court does in a more circuitous manner when it decides that an interest is "fundamental."

Perhaps the most telling accusation which may be directed at the pervasive balancing aspect of the reasonableness test as utilized in Griswold and in other cases is that it invades the rightful province of the legislature by indulging in policy evaluations. ${ }^{52}$ On the other hand, it is this very feature which affords resistance to the tendency to regard the privacy or other independent interest as an absolute which may not be regulated irrespective of the countervailing needs of society. ${ }^{53}$ The reasonableness inquiry also results in the

the state board of examiners refused to allow petitioner to take the bar exam to qualify him for the practice of law, it violated due process because there were no rational grounds for this action. Id. at 246-47. Segregation of public schools in Washington, D.C., was adjudged "not reasonably related to any proper governmental objective, and thus .... an arbitrary deprivation of [plaintiff's] liberty in violation of the Due Process Clause." Bolling v. Sharpe, supra note 49, at 500. Section 9 (a) of the Hatch Act, 53 Stat. 1148 (1939), as amended, 5 U.S.C. $\$ 118$ (i) (1964), forbidding certain partisan political activity by federal employees was upheld in United Pub. Workers v. Mitchell, supra note 49 , as a reasonable regulation desigued to ensure the efficiency and integrity of the civil service. Id. at 102. See Kent v. Dulles, 357 U.S. 116 (1957); West Coast Hotel Co. v. Parrish, 300 U.S. 379, 391-92 (1937); Nebbia v. New York, 291 U.S. 502, 525, 536 (1934); Pierce v. Society of Sisters, supra note 49, at 534-35; Meyer v. Nebraska, supra note 49 , at $399-400$.

52 See note 22 supra.

s2 "Yet the Court under the balancing theory must ask itself the very questionis this worth what it costs?-which the Congress necessarily asked itself, and to which it gave its answer when it decided to take the action." Frantz, The First Amendment in the Balance, 71 YaLE L.J. 1424, 1444 (1962).

${ }^{53}$ This absolutist tendency is implied in the opinion of $\mathrm{Mr}$. Justice Douglas, although he did not consider privacy as an interest independent of the Bill of Rights. 381 U.S. at $485-86$. He has been critical of those who refuse to assert uncquivocally a Bill of Rights freedom against a law which abridges such a guarantee and who resort instead to a balancing or weighing of the conflicting interests. Garrison v. 
"narrowest" decision in the sense that the outcome is dependent not so much on broad, precedential constitutional doctrine but rather on a pragmatic comparison of the imperative quality of the opposing interests as revealed by the factual context presented. ${ }^{54}$ To the extent, then, that it is needful to formulate the constitutional rule of a case in terms no broader than absolutely required by the facts, ${ }^{55} \mathrm{Mr}$. Justice White's opinion offers the preferable dispositive method in Griswold.

Louisiana, 379 U.S. 64, 81-82 (1964) (concurring opinion). As might have been expected, therefore, he did not consider in Griswold any state policies which might justify the regulation. Wholly aside from the main controversy between the "absolutists" and the "balancers" with regard to laws contravening portions of the Bill of Rights, where there is no explicit or clear constitutional directive and a broad state police power is called into question, it would seem advisable for the Court to evaluate the law in view of the needs of a well-ordered society and not solely by its impact on the private lives of the individuals affected by it.

sc An example might best illustrate this conclusion. If, subsequent to Griswold, a criminal action were brought against a defendant under a state sodomy law, see MUeller, Legal Regulation of Sexual Conducr 53-55, 127-32 (1961), he might assert as a defense that the statute in question was unconstitutional as an invasion of his right to privacy, citing Griswold as authority. While the opinion of the Court focused on marital privacy, part of the ratio decidendi involved the recognition that "various guarantees [in the Bill of Rights] create zones of privacy." 381 U.S. at 484. If the allegedly criminal act, which will be assumed to have been committed in the defendant's home, can be brought within this constitutionally secured zone of privacy, the defendant NO might well prevail. Mr. Justice White's due process approach would not allow such a mechanistic resolution of the issue raised; rather, White's thesis narrows the base of the decision. An interest in privacy, even in the context of a man's home, is constitutionally protected only if the state's interest in regulating it in the particular manner chosen is inconsiderable or "unreasonable" when evaluated in light of the quality of the individual interest jeopardized. See note 22 supra. In the hypothetical case, the argument for privacy to permit a person to engage in aberrational sexual practices would not appear by contemporary moral attitudes to be very commanding, and the state could probably defend its statute successfully as a rational means of protecting public morals.

At least one member of the Court was openly concerned at the perhaps far-reaching and unintended effect of the broad constitutional doctrine enunciated in the opinion of the Court. Mr. Justice Stewart commented that he supposed "even after today a State can constitutionally still punish at least some offenses which are not committed in public." 381 U.S. at 530 n.7 (Stewart, J., dissenting).

EE This rule of constitutional adjudication was articulated along with several other rules similar in purpose, by $\mathbf{M r}$. Justice Brandeis in his concurring opinion in Ashwander v. TVA, 297 U.S. 288, 346-47 (1936) (concurring opinion).

It must be noted that limiting the rule of a case to its immediate facts increases the difficulty of the task of the attorney called upon to give reliable advice to a client, the legislator in need of knowing how far a law validly may reach, and the judge faced with the problem of administering justice in terms of that decision as precedent. The process of applying to related contexts a decision grounded on the narrowest possible rationale may be made a matter of guesswork, highly vulnerable to subsequent reversal by a Court which chooses to interpret the restrictive language of the decision as representing a different general proposition of law. A persuasive argnment may be made, therefore, in favor of couching the ratio decidendi of a case in somewhat 
It is somewhat ironic that one of the Court's foremost libertarians is found in the dissent in a case vindicating a personal right as highly valued and seemingly sacrosanct as marital privacy. In this sense Griswold serves dramatically to illustrate the significant shift in thrust of Mr. Justice Black's theory of the fixed concept of due process brought about by recent constitutional developments. That theory was intended to preclude the Court from using its preformed, idiosyncratic notions of natural law and justice as due process criteria by which to strike down economic legislation ${ }^{60}$ or to dilute the force of Bill of Rights immunities. ${ }^{67}$ These concerns have now largely been alleviated. A marked judicial restraint vis-à-vis state regulation of property interests has characterized the attitude of the Court since $1934,{ }^{58}$ while many important Bill of Rights protections have been brought under the aegis of the fourteenth amendment through a selective, case-by-case method rather than by bulk incorporation. ${ }^{59}$ The predominant effect of fixed due process is now, as Black's position in Griswold makes clear, to preclude its advocates from championing a non-enumerated, personal right against state interference. In promoting a greater degree of certainty in due process adjudication, Mr. Justice Black has bound himself to a static conception of the scope of that clause. ${ }^{60}$

broader terms in order to obtain greater certitude at the various stages of the legal process.

${ }^{58}$ Ferguson v. Skrupa, 372 U.S. 726, 727-32 (1963) (Black, J.); Rochin v. California, 342 U.S. 165, 176-77 (1952) (Black, J., concurring); Adamson v. California, 332 U.S. 46, 90 (1947) (Black, J., dissenting).

${ }^{87}$ Id. at 90 (Black, J., dissenting). "I long ago concluded that the accordian-like qualities of this [flexible due process] philosophy must imperil all the individual liberty safeguards specifically enumerated in the Bill of Rights." Rochin v. California, supra note 56, at 177. See Kadish, supra note 20, at 319-20, 336-39; Comment, 58 YALE L.J. 271-73 (1949).

ob Schmidhauser, The Supreme Court as Finat Arbiter in Federal-State Relations, 1789-1957, at 192-93 (1958); Kauper, Trends in Constitutional Interpretation, 24 F.R.D. $155,174-75$ (1959); Strong, supra note 22, at 285, 301-02.

${ }^{6}$ E.g., Malloy v. Hogan, 378 U.S. I (1964) (right against self-incrimination); Gideon v. Wainwright, 372 U.S. 335 (1963) (right to counsel); Edwards v. South Carolina, 372 U.S. 229 (1963) (rights of speech, assembly, petition for redress of grievances); Shelton v. Tucker, 364 U.S. 479 (1960) (freedom of association); Staub v. City of Baxley, 355 U.S. 313 (1958) (freedom of speech); Cantwell v. Connecticut, 310 U.S. 296 (1940) (freedom of religion); see Redlich, supra note 42, at 792-93.

${ }^{0}$ The delimiting of a judge's power of review under the due process clause by conditioning its exercise upon the violation of a specific, concrete, textual guarantce is precisely the result Mr. Justice Black hopes to achieve by his approach to this area of fourteenth amendment adjudication. He believes these restraints necessary to prevent the Court from appointing to itself what would amount to a "supervisory veto over the wisdom and value of legislative policies." 381 U.S. at 512 (dissenting opinion). See notes 34,36 supra and accompanying text. A degree of flexibility is still 
The extent to which the Court will expand the developing and now partially secured constitutional "right of privacy" remains open to conjecture. One may argue that the Court has merely adapted the familiar if somewhat ill-defined notion of an interest in privacy as a conceptual vehicle by which to establish two specific and closely interrelated rights: the right to make fundamental decisions concerning family planning and the right to exercise the conjugal privilege in marriage free from state interference. Even with this restricted view of the import of Griswold, it is evident that the decision will be cogently apposite should the question of the validity of state birth control legislation or certain types of compulsory sterilization laws be hereafter brought before the Court. $^{.1}$ On the other hand, both friend and foe of Griswold have suggested that the Court has seized a propitious opportunity to lay down precedent for future use in other problematic areas in which an interest in privacy may be paramount. ${ }^{62}$ The ultimate accuracy of this observation will depend on which of the varied philosophies concerning the essential nature of the due process guarantee displayed in Griswold prevails in any given case. By failing to reach an actual, unequivocal accord on this issue, the Court has given little positive indication of its future response in these areas.

available to Mr. Justice Black under fixed due process, moreover, in the process of defining the content of the Bill of Rights immunities, which have been capable of significant expansion and coutraction. See Comment, 58 YALE L.J. 268, 276 (1949). Cf. C. BLACK, Mr. Justice Black, the Supreme Court, and the Bill of Rights, in THF OCcasions of Justice 92.98, 101 (1963).

o1 Redlich, supra note 42 , at 802 , 809-10. See 381 U.S. at 496-97 (Goldberg, J., coucurring).

${ }^{62}$ N.Y. Times, June 15,1965, p. 25 , col. 2. The use in state trials of evidence obtained by wiretapping and other forms of eavesdropping by state officials, and the statutory prohibition of miscegeuation, e.g., VA. CODE ANN. $\S 20-59$ (1960), involve related and arguably strong privacy iuterests. 